\title{
Companies' Use of Whistle-Blowing to Detect Fraud: An Examination of Corporate Whistle-Blowing Policies
}

\author{
Gladys Lee $\cdot$ Neil Fargher
}

Received: 31 August 2011/Accepted: 4 May 2012/Published online: 19 May 2012

(C) Springer Science+Business Media B.V. 2012

\begin{abstract}
In order to provide an effective whistle-blowing system, it is expected that companies would provide employees with a high level of disclosure regarding the whistle-blowing process. This study investigates variation in the extent of whistle-blowing disclosures. As a measure of whistle-blowing implementation, this study further examines the provision of a hotline channel. The results suggest that the extent of whistle-blowing disclosures is positively associated with the permissibility of anonymous reporting and organisational support for whistle-blowing, the number of external directors on the audit committee, and the existence of concentrated shareholdings. The mere existence of whistle-blowing disclosures could simply be symbolic. The findings also indicate a greater likelihood of the provision of hotlines when companies are larger in size, have a higher level of current inventory, are cross-listed in the US, and permit anonymous reporting.
\end{abstract}

Keywords Whistle-blowing · Fraud - Internal reporting · Whistle-blowing policies $\cdot$ Hotlines

\section{Introduction}

Fraud appears to be increasing in terms of frequency and cost, with employees and management being the greatest perpetrators (Coram et al. 2008; KPMG 2009). A global survey found that at least $30 \%$ of companies had experienced fraudulent misconduct (Pricewaterhousecoopers 2009).

G. Lee $(\bowtie) \cdot$ N. Fargher

Research School of Business, Australian National University, Canberra, Australia

e-mail: gladys.lee@anu.edu.au
Whistle-blowing is argued to be an effective mechanism to combat fraud (ACFE 2010). Prior research on whistleblowing has focused on who the whistle-blowers are, individual reporting intentions, the effectiveness of whistle-blowing systems, and the consequences of whistleblowing (Mesmer-Magnus and Viswesvaran 2005; Miceli et al. 2008; Dyck et al. 2010; Bowen et al. 2010). We extend prior research that examines the implementation of effective whistle-blowing systems in companies by examining the determinants of the extent of whistle-blowing disclosures and the implementation of hotlines channels.

Employees often become aware of a wrongdoing (Appelbaum et al. 2006; Kaplan et al. 2010; Moberly 2006), but do not necessarily report the wrongdoing. One response that has been argued to help detect misconduct and to minimise the consequences of wrongdoing is for companies to implement a system to facilitate whistle-blowing (Paul and Townsend 1996; Miceli et al. 2009; ACFE 2010). Whistle-blowing systems are important because the absence of an effective system minimises the likelihood that an employee will blow the whistle on misconduct (Near and Miceli 1995). Yet, it is evident from prior studies that there are disparities in internal whistle-blowing systems across companies and countries (Calderón-Cuadrado et al. 2009; Hassink et al. 2007; Weaver et al. 1999).

Systems to support whistle-blowing have been widely included in legislation. In the United States (US), the Sarbanes-Oxley Act (Sarbanes-Oxley 2002) requires listed companies to have some form of system for internal reporting by employees. The provisions in the Act provide protection for whistle-blowers and mandate that audit committees establish whistle-blowing procedures (Miceli et al. 2008; Sarbanes-Oxley 2002), but does not mandate the use of particular reporting channels. Since the Sarbanes-Oxley Act (SOX) of 2002, corporate whistle- 
blowing provisions have been introduced in countries such as the United Kingdom (UK), ${ }^{1}$ the Netherlands ${ }^{2}$ and Belgium $^{3}$ (Hassink et al. 2007).

Despite the legislative support for whistle-blowing there is relatively little research on which companies benefit from the use of whistle-blowing systems. The voluntary implementation of whistle-blowing systems in Australian companies provides an opportunity to investigate the factors important to establishing a sound internal reporting system. The Australian legislation encourages whistleblowing by providing some form of protection for whistleblowers in the Corporations Act $2001,{ }^{4}$ however, there is no legislation that mandates the compulsory implementation of a whistle-blowing system in companies. 5 The Australian Securities Exchange's 'Principles of Good Corporate Governance' recommends that companies follow the guidelines of Standards Australia to develop a whistle-blower protection program (Standards Australia 2003). This standard recommends developing an internal whistle-blowing system that complements the companies' code of ethics. With limited legal provisions, the implementation of whistle-blowing systems in Australia has been said to be developing in an ad hoc manner (Brown 2009). The inconsistency in the implementation of whistle-blowing systems in Australian companies provides an opportunity to examine variation in the factors associated with the adoption of such systems.

We examine the cross-sectional determinants of the extent of investment in whistle-blowing systems as revealed in corporate disclosures and by the specific provision of a hotline service. In order to provide an effective whistle-blowing system, it is expected that companies would provide employees with a high level of disclosure regarding the whistle-blowing process. This study investigates variation in the extent of whistle-blowing disclosures. The extent of disclosures made within the company's whistle-blowing policy is examined using a checklist recommended by Standards Australia (2003). A greater extent of disclosures is an indication that a better whistle-blowing system has been put in place. We investigate the firm's economic, legal, ethical and corporate governance environment as potential determinants that are likely to affect the extent of disclosure regarding whistle-blowing systems.

The mere existence of disclosures in a whistle-blowing policy, however, does not assure that an effective whistle-

\footnotetext{
1 Combined Code on Corporate Governance, 2003.

2 Tabaksblat Code, 2005.

3 Code on Corporate Governance, 2004.

4 Section 9.4 AAA of the Corporations Act 2001.

5 There is also evidence from surveys that whistle-blowing systems have not been comprehensively implemented in all Australian companies (KPMG 2009; ACFE 2010).
}

blowing system has been put in place. A standard policy alone may lack credibility (Hassink et al. 2007; Weaver et al. 1999). The adoption of disclosures and ethical codes could simply be symbolic (Weaver et al. 1999). The use of a dedicated hotline service is highly visible and helps to increase the credibility of the whistle-blowing system. The implementation of a hotline channel requires additional cost. As such, implementing a dedicated hotline channel signals management's commitment to whistle-blowing.

We find that the extent of whistle-blowing disclosures is positively associated with the strength of organisational support for whistle-blowing, the provision of anonymous reporting, the number of external directors on the audit committee and the existence of concentrated substantial shareholdings. The implementation of hotline services is positively affected by economic factors (bigger size firm, having higher levels of inventory, being more geographically diversified), ethical environment (organisational support for whistle-blowing and permissibility of anonymous reporting) and legal determinants (cross-listing status in the US). The establishment of hotlines is not significantly associated with the level of corporate governance.

This article contributes to previous research by identifying the factors associated with the use of whistle-blowing systems as documented in company policy disclosures. While whistle-blowing has been explicitly regulated in some jurisdictions, this research suggests that companies interested in good corporate governance will voluntarily adopt policies consistent with an effective whistle-blowing system. The findings further suggest that the implementation of costly whistle-blowing mechanisms such as hotlines are subject to economic, legal and ethical factors, with, for example, companies with higher inventories at risk or more geographic dispersion more likely to invest in whistleblowing channels such a hotlines where benefits are more likely.

This article is organised as follows. Background on prior research on whistle-blowing systems is provided in second section. The model development is discussed in third section, while fourth section describes the sample and the data collection methods used. Fifth section presents the results documenting the factors that are associated with the extent of whistle-blowing disclosures provided and the implementation of a hotline channel. Finally, sixth section provides some additional analysis followed by the conclusion.

\section{Prior Research on Whistle-Blowing Systems}

Whistle-blowing is commonly defined as

the disclosure by organization members (former or current) of illegal, immoral, or illegitimate practices 
under the control of their employers, to persons or organizations that may be able to effect action (Near and Miceli 1985, p. 4).

A good internal whistle-blowing system serves in the timely detection of fraud, permitting the company to correct the wrongdoing and minimise the costs of the fraud (Chung et al. 2004; Paul and Townsend 1996). ${ }^{6}$ In addition, because employees are encouraged to act within the code of ethics, this increases the safety and well-being of the organisation, avoids damage claims and legal regulation, increases the satisfaction of employees and fosters greater work commitments and loyalty (Bowden and Smythe 2009; Miceli et al. 2009; Paul and Townsend 1996). As such, a sound internal whistle-blowing system increases the likelihood of internal reporting of wrongdoing, and helps management to avoid the negative costs of external whistle-blowing that may be highly damaging to a company's reputation. ${ }^{7}$ Assuming that effective whistle-blowing systems require adequate disclosure to employees, we examine the internal reporting system by exploring the extent of disclosures included in whistle-blowing policies.

\section{Whistle-Blowing Policy Disclosures}

Whistle-blowing disclosures are important in establishing an effective whistle-blowing system because studies have found a positive relationship between the quality of ethical codes and policies and reporting intentions (Barnett et al. 1993; Schwartz 2001). For example, Barnett et al. (1993) found that employees disclosed more wrongdoings when companies had internal policies in place and Somers (2001) found that companies with ethical codes experienced fewer wrongdoings. A related study by Adams et al. (2001) found that employees in companies that adopted ethical codes rated themselves as being more ethical as compared to employees from companies without such ethical codes. As such, the existence and quality of a whistle-blowing policy affects ethical and reporting behaviours among employees, and serves as an indication of the quality and likely effectiveness of the whistle-blowing system in a company.

Previous research examining disclosures regarding code of conducts and whistle-blowing systems provides evidence of variation in whistle-blowing policies across companies and countries (Calderón-Cuadrado et al. 2009; Hassink et al. 2007; Singh 2006; Singh et al. 2005). Singh

\footnotetext{
${ }^{6}$ For a more complete review of accounting research relevant to whistle-blowing, refer to Bedard et al. (2008).

7 Bowen et al. (2010) provide empirical evidence that firms subject to external financial whistle-blowing events experienced lower marketadjusted 5-day stock price reaction, more earnings restatements and shareholder lawsuits, and more negative future operating performance and stock return performance.
}

(2006) compared the codes of Canada's largest corporation in 1992 and 2003. He found that the biggest changes were related to reportable environmental issues and also that the current codes were found to be concerned with conduct against the firm rather than on behalf of the firm.

Hassink et al. (2007) examined the contents of whistleblowing policies of 56 leading European companies and found that most required employees to report breaches of internal policies and external regulations or laws. The companies often provided confidentiality guarantees and allowed anonymous reporting, though anonymous reporting was sometimes discouraged. They found that little information was given by the European companies on how whistle-blowers would be treated.

The voluntary corporate disclosure literature suggests that disclosures are affected by economic determinants such as the size of the firm, capital intensity, the degree of involvement in advertising, and leverage (Beneish and Chatov 1993; Clarkson et al. 2006; Holder-Webb et al. 2008; Lang and Lundholm 1993; Meek et al. 1995). Calderón-Cuadrado et al. (2009), however, found no economic determinants in establishing whistle-blowing procedures. They suggested that the lack of statistical significance was due to homogeneity in their data set, and proposed that future research examine the economic determinants of hotlines.

\section{Reporting Hotlines}

A standard reporting policy may lack credibility (Hassink et al. 2007). Mere disclosures within a whistle-blowing policy do not guarantee that a good whistle-blowing system is in place (Weaver et al. 1999). Weaver et al. (1999) find that the majority of companies in their sample have only committed to the low cost, symbolic side of ethics management through the adoption of codes and policies. Most of these companies did not ensure that the ethical codes and policies are actually implemented and put in practice. However, establishing an effectiveness whistle-blowing system is not just by developing a good whistle-blowing policy, but also in implementing and monitoring the whistle-blowing system.

An effective whistle-blowing system would also be expected to have effective whistle-blowing procedures (Hassink et al. 2007). Standards Australia (2003) recommends that companies establish dedicated and highly visible reporting mechanisms such as hotlines. Dedicated reporting hotlines are one of the channels most often suggested to be effective in detecting fraud (ACFE 2010; Bierstaker et al. 2006; Holtfreter 2005). A recent survey (ACFE 2010) finds that among anti-fraud controls, the presence of hotlines reduces the median fraud loss by the largest percentage. 
Research on reporting hotlines has largely been in the context of the implementation and characteristics of whistle-blowing systems using descriptive studies (Calderón-Cuadrado et al. 2009; Hassink et al. 2007; Weaver et al. 1999). Weaver et al. (1999) reported that $57 \%$ of the Fortune 1000 firms provided hotline channels for the reporting of misconduct. An examination of 56 top European companies found that $38 \%$ employed the use of hotline services (Hassink et al. 2007). A study of 150 transnational companies by Calderón-Cuadrado et al. (2009) found that $57 \%$ of European companies, and $95 \%$ of North American companies have dedicated hotlines services.

Calderón-Cuadrado et al. (2009) examined the code of conduct related to internal reporting hotlines of 150 transnational companies. They found distinct differences within, and between, countries. For example, while $95 \%$ of North American companies in their sample had internal reporting hotlines, European companies had only $57 \%$. North American companies were also found to be more likely to disclose provisions for anonymity, confidentiality and for no retaliation.

The usage of hotlines appears to vary across companies. Weaver et al. (1999) reported that $25 \%$ of firms received not more than one call per 10,000 employees in a month, $46 \%$ reporting more than $2-9$ calls, $12 \%$ receiving $10-19$ calls and another $18 \%$ had received 20 or more calls. The variation in the call rates is argued to be partly driven by the perceived role of the hotlines (Weaver et al. 1999). The role of hotlines differs based on its orientation. Hotlines can be oriented towards controlling and regulating behaviours; alternatively, hotlines can be oriented to encourage reporting behaviours. Weaver et al. (1999) suggest that employees are less likely to use hotlines that fulfil a policing or regulating role.

Studies have suggested that hotline services are an effective reporting mechanism and contribute to developing an effective whistle-blowing system by encouraging reporting of misconduct and enhancing deterrence (see for example, Asgary and Mitschow 2002; Bierstaker et al. 2006; Calderón-Cuadrado et al. 2009). Firstly, a hotline channel allows anonymous reporting of misconduct, and this helps to reduce the perceived risk of retaliation of a potential whistle-blower (Bierstaker et al. 2006; Holtfreter 2005). Calderón-Cuadrado et al. (2009) found that companies which are more proactive in getting employees to report misconduct are more likely to offer the permissibility of anonymous reporting through hotline services.

A 24-h ethics hotline permits employees to report misconduct confidentially at their own convenience and at anytime (Asgary and Mitschow 2002). Because hotlines can be maintained off-site, employees that are located in other geographical locations can make use of the same reporting channel, and this also increases cost-effectiveness (Bierstaker et al. 2006; Calderón-Cuadrado et al. 2009). Finally, the implementation of hotline services increases the potential perpetrators perceived risk of being reported and helps to reduce unethical behaviour in the workplace (Bierstaker et al. 2006).

In summary, prior research has advocated the implementation of an effective whistle-blowing system to detect and deter misconduct in the workplace. We assume that a high level of disclosure is a necessary, but not necessarily sufficient, condition in contributing to an effective whistleblowing system by helping to encourage greater reporting by employees (Barnett et al. 1993; ACFE 2010). Prior studies observe that the extent of whistle-blowing disclosures and establishment of reporting hotlines vary across companies (Hassink et al. 2007; Calderón-Cuadrado et al. 2009). We extend prior research by examining the determinants of the extent of whistle-blowing disclosures and the implementation of hotlines channels.

\section{Cross-Sectional Determinants of Whistle-Blowing Disclosures}

The establishment of an effective internal whistle-blowing system is assumed to require a high level of disclosure to employees. We initially examine the extent of corporate disclosure as a measure of the extent of the implementation of an effective whistle-blowing system. We predict that the extent of the whistle-blowing systems implemented, as reflected in their corporate disclosures, will be influenced by the costs and benefits of implementing such a system. We examine factors related to the firm's economic, legal, ethical and corporate governance environment. These factors include the size of the firm, the level of inventory, geographical dispersion of the firm, cross-listing in the US, explicitly stated organisational support for whistle-blowing, permissibility of anonymous reporting, the numbers of outside directors on the audit committee and the existence of concentrated shareholdings.

\section{Economic Determinants}

Size

The voluntary corporate disclosure literature suggests that larger firms provide greater and higher quality disclosures than smaller firms because of competitive cost advantage (Clarkson et al. 2006; Lang and Lundholm 1993; Meek et al. 1995). Calderón-Cuadrado et al. (2009) also suggest that direct control mechanisms may be less effective when companies grow bigger and thus may encourage the use of reporting misconduct through hotline channels. 
Accordingly, it is predicted that larger companies are more likely to implement and disclose the provision of hotlines. Holder-Webb et al. (2008) specifically find that whistleblowing procedures are more likely to be disclosed by large companies. We therefore expect that larger companies are more likely to have the resources to develop a better whistle-blowing system.

\section{Inventory}

A common type of fraud among employees is inventory fraud (Hillison et al. 1999; KPMG 2009). Firms with greater levels of inventory are likely to be more exposed to internal control risks related to the proper measurement and recording of inventory, misreporting due to theft, and timely recognition of inventory obsolescence (AshbaughSkaife et al. 2007). Ashbaugh-Skaife et al. (2007) found that firms with higher levels of inventory are more likely to report internal control deficiencies. It is predicted that companies with larger inventories would be more likely to implement a better whistle-blowing system in order to minimise the risk of fraud.

\section{Dispersion}

Firms that have a greater geographical dispersion are likely to face greater internal control problems (Ashbaugh-Skaife et al. 2007). Direct monitoring may be difficult and costly with greater geographical dispersion because of language differences or the lack of a physical presence of a monitoring body. As such, there are greater incentives for a company to put in place better whistle-blowing policies and provide more disclosures on whistle-blowing. Further, to overcome geographical distances, a company may prefer the use of hotlines as a form of communication (Oldendorf 2007). Calderón-Cuadrado et al. (2009) suggest that a company with branches in many different countries may prefer establishing a common procedure of reporting misconduct through hotlines. Therefore, it can be expected that there will be better implementation of a whistle-blowing system in companies which operate in more geographical regions.

\section{Legal Environment}

The passage of the Sarbanes-Oxley Act (Sarbanes-Oxley 2002) requires the audit committees of all US and non-US listed companies to establish procedures for the receipt, retention and treatments of complaints received by the issuer [the company] regarding accounting, internal accounting controls, or auditing matters; and the confidential, anonymous submissions by employees of the issuer [the company] of concerns regarding questionable accounting or auditing matter under Section 301(4) of the Act. Thus, companies that are cross-listed in the US are likely to have established better internal reporting policies. In achieving compliance with the provisions of Section 301(4) of the SOX Act, many companies have also responded by establishing hotline services (Worlton 2005). As such, firms cross-listed on US exchanges are expected to be more likely to establish a sound whistle-blowing system.

\section{Ethical Environment}

\section{Support for Whistle-Blowing}

The organisational climate affects an individual's whistleblowing decision (Near and Miceli 1985; Chung et al. 2004; McDonald 2000). Companies that are more supportive of whistle-blowing are expected to be more likely to establish better reporting mechanisms. McDonald (2000) argues that companies that encourage whistle-blowing are more likely to implement a hotline service because hotlines facilitate open communication. Support for whistle-blowing is measured by examining whether the company explicitly state its support for whistle-blowing in the whistle-blowing policy.

\section{Anonymous Reporting}

Anonymous reporting systems reduce a whistle-blower's personal costs of reporting such as facing sanctions from their employers, being ostracised by their co-workers, verbal threats and unfavourable job evaluations (Bjørkelo et al. 2010). A company may, however, be reluctant to implement an anonymous reporting channel because it requires more resources, and can hinder or complicate investigation (Calderón-Cuadrado et al. 2009; Hassink et al. 2007). As such, companies that permit anonymous reporting are likely to be more supportive of whistleblowing and would be expected to provide a greater extent of whistle-blowing disclosures. A common mechanism used to facilitate anonymous reporting is through the use of hotline services (Worlton 2005). Thus, it is also predicted that companies that allow anonymous reporting are likely to have implemented a better whistle-blowing system.

\section{Corporate Governance Determinants}

Internal governance structure of a firm can influence the use of internal control mechanisms to ensure compliance, credibility and detect fraud (Coram et al. 2008; Davidson et al. 2005). Agency theory suggests that in order to align the interests of shareholders and management, bonding mechanisms have to be put in place (Jensen and Meckling 
1976). A greater number of external directors on the audit committee and the existence of concentrated shareholdings may increase the pressure for a better whistle-blowing system to be established for monitoring purposes (Davidson et al. 2005). Thus, it can be predicted that with better corporate governance, there will be a greater extent of whistle-blowing disclosures and it is more likely that a hotline service will be established.

In summary, we predict that the implementation of better whistle-blowing systems, as measured by extent of corporate disclosure and implementation of a hotline service, is associated with the size of the firm, the level of inventory, geographical dispersion of the firm, cross-listing in the US, organisational support for whistle-blowing, permissibility of anonymous reporting, the numbers of outside directors on the audit committee and the existence of concentrated shareholdings. Based upon the above discussion, the following model is estimated to analyse the extent of whistle-blowing disclosures:

$$
\begin{aligned}
\operatorname{DSCORE}_{i, t}= & \beta_{0}+\beta_{1} \mathrm{LTA}_{i, t}+\beta_{2} \mathrm{INV}_{i, t}+\beta_{3} \mathrm{SEG}_{i, t} \\
& +\beta_{4} \mathrm{XLIST}_{i, t}+\beta_{5} \mathrm{SUP}_{i, t}+\beta_{6} \mathrm{ANON}_{i, t} \\
& +\beta_{7} \mathrm{AUDC}_{i, t}+\beta_{8} \mathrm{SUB}_{i, t}+\varepsilon_{i, t}
\end{aligned}
$$

where DSCORE is the whistle-blowing disclosure score, measured on a 18-point scale; LTA is the natural logarithm of total assets in dollars; INV is the natural logarithm of the value of current inventories in dollars; SEG is the number of geographical business segments; XLIST is the indicator variable coded ' 1 ' if company cross-lists in the US, ' 0 ' otherwise; SUP is the indicator variable coded ' 1 ' if a company encourages whistle-blowing, as observed in their whistle-blowing policy are used, ' 0 ' otherwise; ANON is the indicator variable coded ' 1 ' if company discloses that anonymous reporting is allowed, ' 0 ' otherwise; AUDC is the number of external directors on the audit committee; SUB is the percentage held by largest substantial shareholder; $i$ is the company, and $t$ is the year 2010 .

The model is also estimated using the existence of a hotline (HOTLINE) as the measure of whistle-blowing system implementation. An indicator variable takes the value of ' 1 ' if it disclosed that a company provides a hotline service and ' 0 ' otherwise.

\section{Research Methodology}

Sample

Prior studies have found that the extent of disclosures varies significantly by company size (Holder-Webb et al. 2008). Because smaller companies can find a whistle-blowing policy uneconomic, this study limits the sample to the larger companies listed on the S\&P/ASX 200 Index. The S\&P/ASX 200 Index is a commonly used institutional benchmark in Australia to identify the largest companies listed on the ASX. This study examines the whistle-blowing policies of Australian companies in the S\&P/ASX 200 Index (as of 3 September 2010). ${ }^{8}$

Disclosures are sourced from the corporate websites of the companies and their Corporate Governance Statements in annual reports. The frequency and extent of the disclosure of whistle-blowing policies are presented in Table 1. A company is classified as having a whistle-blowing policy disclosure if it discloses procedures for the reporting of misconduct. For the purposes of this analysis a single disclosure, to the effect that misconducts should be reported to an individual, is not considered to be a whistleblowing policy. Of the 200 companies examined, 31 companies do not disclose that they have whistle-blowing policies on their website or in the Corporate Governance Statement of their annual report. Another 62 companies only provide cursory partial (or summarised) disclosures of their whistle-blowing policies, and full disclosures are not publicly available on their websites. These companies are excluded from the sample because the precise nature of their whistle-blowing systems is not known. The resulting sample with sufficient, publicly available whistle-blowing policies includes 107 companies. The sample size is small but comparable to prior research. ${ }^{9}$

\section{Data Collection for Whistle-Blowing Disclosure Scores}

Whistle-blowing disclosures are assessed using an adapted checklist (see Table 2) of 'Suggested checklist of matters to be addressed in a whistle-blower protection program' as recommended by Standards Australia (2003). Our measure of the extent of whistle-blowing disclosures is a self-constructed index (DSCORE) based on a recommended disclosure checklist provided by Standards Australia (2003). The disclosure checklist, as reported in Table 2, contains 18 disclosure items on the whistle-blowing process and

\footnotetext{
8 The whistle-blowing policies of the next 100 largest companies were also examined, and there were significantly less disclosures provided by these companies. As company size appeared to be the dominant determinant of non-disclosure the sample was restricted to the largest companies with a viable choice to implement and disclose a whistle-blowing system. Alternately using companies from only the larger S\&P/ASX 100 index results in similar coefficient estimates, but are not statistically different from zero in this smaller sample.

9 The sample is larger than Hassink et al. (2007) which examined the whistle-blowing policies of 56 European companies and Singh (2006) which analysed 80 ethical codes of Canadian companies. The sample is slightly smaller than Beneish and Chatov's (1993) study of 160 firms, and Calderón-Cuadrado et al. (2009) sample of 153 transnational companies.
} 
Table 1 Sample selection

\begin{tabular}{lll}
\hline Description & $\begin{array}{l}\text { Number of } \\
\text { companies }\end{array}$ & $\begin{array}{c}\text { Percentage of } \\
\text { companies }\end{array}$ \\
\hline Initial selection of companies from the S\&P/ASX 200 Index & 200 & 100 \\
$\begin{array}{l}\text { Companies that do not disclose their whistle-blowing policies on their } \\
\text { website or in their corporate governance statement }\end{array}$ & $(31)$ & 15.5 \\
Companies that only provided cursory whistle-blowing policy disclosures & $(62)$ & 31.0 \\
Final sample of companies with detailed, publicly available whistle-blowing policies & 107 & 53.5 \\
\hline
\end{tabular}

The table describes the frequency of the disclosure of whistle-blowing policies by large Australian companies that are part of the S\&P/ASX 200 Index. The final sample size used in this study consists of the 107 companies with detailed, publicly available reporting policies from their annual report or corporate website. The sample is restricted to the S\&P/ASX 200 companies because most of the smaller companies do not disclose sufficient information on whistle-blowing policies

protection given that is likely to be important to a potential whistle-blower. For example, Standards Australia (2003) recommends that reports should be kept confidential. Based on this recommendation, we have included an item in the checklist (item 9 in Table 2) that examined whether a company had disclosed that reports will be kept confidential. Standards Australia (2003) also recommends the provision of a whistle-blowing protection officer. Based on this recommendation, an item on our checklist was to examine whether companies had disclosed the appointment of a whistle-blowing protection officer (item 15 in Table 2).

The checklist was applied to the whistle-blowing policy of each company to determine the extent of whistleblowing disclosures. For each disclosure item, the existence of the disclosure was coded ' 1 ' if present; and ' 0 ' otherwise. To verify the coding, an independent coder also classified a sub-sample of $15 \%$ of the company observations with a resulting inter-rater correlation of 0.96 between the codes assigned. We adopt an unweighted index and the

Table 2 Frequency of items disclosed in whistle-blowing policies

\begin{tabular}{|c|c|c|}
\hline No. & Disclosure item & $\begin{array}{l}\text { Frequency of item being reported by } \\
\text { companies in the sample }(n=107)(\%)\end{array}$ \\
\hline 1 & $\begin{array}{l}\text { A statement of the entity's commitment to culture of high corporate } \\
\text { compliance and ethical behaviour }\end{array}$ & 59.81 \\
\hline 2 & Commitment to regularly review the policy & 34.58 \\
\hline 3 & Provision of training & 13.08 \\
\hline 4 & Scope applies to employees (including contractors and consultants) & 100.00 \\
\hline 5 & Scope applies to non-employees (customers, general public) & 14.02 \\
\hline 6 & Guidelines on reportable issues & 98.13 \\
\hline 7 & Guidelines on who to report to & 99.07 \\
\hline 8 & Guidelines on how to report & 96.26 \\
\hline 9 & A statement that report will be treated as confidential & 75.70 \\
\hline 10 & A statement that different individuals will receive and investigate the report & 36.45 \\
\hline 11 & A statement on how the report will be handled & 41.12 \\
\hline 12 & $\begin{array}{l}\text { A statement on whether whistle-blower will be notified on commencement } \\
\text { of investigation }\end{array}$ & 9.35 \\
\hline 13 & $\begin{array}{l}\text { A statement on whether whistle-blower will be notified on whistle-blowing } \\
\text { progress }\end{array}$ & 15.89 \\
\hline 14 & A guarantee that whistle-blowers will receive feedback & 36.45 \\
\hline 15 & Appointment of a welfare/whistle-blowing protection officer & 12.15 \\
\hline 16 & No retaliation by company, if report made in good faith & 77.57 \\
\hline 17 & A statement that protection is given & 56.07 \\
\hline 18 & $\begin{array}{l}\text { Description of the specific protection given from and the actions that will be } \\
\text { taken }\end{array}$ & 27.10 \\
\hline
\end{tabular}

These items are adapted from the 'Suggested checklist of matters to be addressed in a whistle-blower protection program' (Standards Australia 2003). For each disclosure item, the existence of the disclosure was coded ' 1 ' if present; and ' 0 ' otherwise. The primary measure of disclosure score is the count of items disclosed. Alternate measures are considered in the sensitivity analysis 
initial disclosure score is the simple sum of all disclosures made, generating an ordinal measure of the extent of whistle-blowing disclosures for each firm. Alternate scoring approaches were considered and are discussed in the sensitivity analysis. Eighteen disclosure items were examined from the whistle-blowing policies of companies in the sample, giving a maximum score of 18. Higher scores would represent greater overall whistle-blowing disclosure.

The frequency of the items being disclosed by companies in the sample is reported in Table 2. All companies in the sample provide a statement that the scope of the whistle-blowing policy applies to employees. Only 14.02 $\%$ disclose that the policy extends to non-employees. The majority of companies in the sample provide guidelines on reportable issues (98\%), to whom an individual should report (99\%), and the reporting procedures (96\%). There are comparatively fewer disclosures provided by the companies on how the whistle-blowing reports are handled. Few companies disclose that the whistle-blower will be notified on commencement of the investigation (9.35\%), on the progress $(16 \%)$ or be guaranteed feedback (36\%). Finally, few companies disclose that they provide training on whistle-blowing (13\%) even though it is recommended by Standards Australia (2003). This initial analysis provides support of the ad hoc development of whistle-blowing in Australia (Brown 2009). Overall the descriptive data suggests that, even though the sample is restricted to large companies with whistle-blowing policy disclosures, most firms in the sample are not providing comprehensive disclosure of policies that are consistent with the recommendations from Standards Australia (2003) for an effective whistle-blowing system.

\section{Empirical Results}

\section{Descriptive Statistics}

Descriptive statistics for the sample are provided in Table 3. The mean whistle-blowing disclosure score is 9.03 and the median is 9 from a possible score of 18. Less than half of the firms $(37 \%)$ disclosed that they provide hotline services. As expected, the companies are relatively large. The $\log$ of total assets and inventory are used to mitigate the potential impact of extreme observations on the analysis. ${ }^{10}$ The mean (2.57) number of geographical segments indicates that the average firm in this sample has operations outside of Australia. The majority of the firms do not explicitly state their support for internal reporting in their

\footnotetext{
${ }_{10}$ A dollar is added to current inventory before taking the natural log where the value of inventory is zero.
}

whistle-blowing policy (39\%) and just half of the firms disclose that anonymous reporting is permitted (50\%). Firms in this sample typically have three external directors on their audit committees and their largest shareholder holds approximately $17 \%$ of the total amount of shares. The mean of cross-listed firms is $11 \%$ and is reasonably close to a sample used by Salman and Carson (2009) for firms in the ASX Top 500 (14\%).

Table 4 reports non-parametric correlations between the variables of interest. The extent of whistle-blowing disclosures is positively associated with the implementation of a hotline channel, organisational support for whistleblowing and permissibility of anonymous reporting. The disclosure of the implementation of a hotline channel is positively associated with the provision of whistle-blowing protection, firm size, level of inventory, number of geographical segments, cross-listing status, organisational support, and the allowance of anonymous reporting.

Tobit Regression Analysis of the Extent of Whistle-Blowing Disclosures

As the whistle-blowing disclosure score is a bounded variable we report results using a Tobit model. As discussed above, the score is computed from disclosures based on the company's whistle-blowing policy, using an adapted checklist from recommendations by Standards Australia (2003). Results of the analysis are presented in Table 5. The model has significant explanatory power with a pseudo $R^{2}$ of $12.34 \%$. We find that four variables are significant in this model-organisational support (SUP), the provision of anonymous reporting (ANON), outside directors on the audit committee (AUDC) and substantial shareholdings (SUB). Two of the variables (SUP and ANON) are determinants related to the ethical environment. The coefficient on organisational support and is positive and significant (coefficient $=2.101, p=0.000$ ). ANON measures the permissibility of anonymous reporting and is positive and is also significant at the $1 \%$ level (coefficient $=3.299$, $p=0.000$ ). The results are consistent with a company's ethical environment playing a role in determining the extent of disclosures provided within a company's whistleblowing policy.

The other two significant coefficients are determinants related to the corporate governance environment. The number of external directors on the audit committee (AUDC) is positive and significant (coefficient $=0.463$ ) at the $5 \%$ significance level $(p=0.044)$. SUB measures the percentage held by the largest substantial shareholder and is positive and significant (coefficient $=0.046$ ) at the $5 \%$ significance level $(p=0.038)$. Stronger corporate governance is likely to increase the extent of disclosures provided for in the whistle-blowing policy. 
Table 3 Descriptive statistics

\begin{tabular}{|c|c|c|c|c|c|}
\hline & Mean & Standard deviation & Median & Minimum & Maximum \\
\hline DSCORE & 9.03 & 3.121 & 9 & 4 & 16 \\
\hline HOTLINE & 0.37 & 0.486 & 0 & 0 & 1 \\
\hline Total assets ( $\$$ millions) & 25,618 & $97,069.8$ & $2,564.4$ & 10.073 & 654,000 \\
\hline LTA & 21.845 & 1.848 & 21.665 & 16.125 & 27.206 \\
\hline INV & 13.349 & 8.518 & 17.997 & 0.000 & 22.557 \\
\hline SEG & 2.57 & 1.311 & 3 & 1 & 5 \\
\hline XLIST & 0.11 & 0.317 & 0 & 0 & 1 \\
\hline SUP & 0.39 & 0.491 & 0 & 0 & 1 \\
\hline ANON & 0.50 & 0.502 & 0 & 0 & 1 \\
\hline AUDC & 3.21 & 1.163 & 3 & 1 & 9 \\
\hline SUB & 16.667 & 0.113 & 14.030 & 1.040 & 62.200 \\
\hline
\end{tabular}

DSCORE whistle-blowing disclosure score measured on an 18-point scale, higher scores indicating greater disclosures; HOTLINE indicator variable coded ' 1 ' if hotlines are used, ' 0 ' otherwise; LTA log of total assets in dollars; INV natural logarithm of current inventories in dollars; SEG number of geographical business segments; XLIST indicator variable coded ' 1 ' if company cross-lists in the US, ' 0 ' otherwise; SUP indicator variable coded ' 1 ' if support for whistle-blowing is explicitly mentioned in a company's whistle-blowing policy, ' 0 ' otherwise; $A N O N$ indicator variable coded ' 1 ' if company allows anonymous reporting, ' 0 ' otherwise; AUDC number of external directors on the audit committee; SUB percentage held by largest substantial shareholder

Table 4 Spearman correlations $(n=107)$

\begin{tabular}{|c|c|c|c|c|c|c|c|c|c|c|}
\hline & & DSCORE & HOTLINE & LTA & INV & SEG & XLIST & SUP & ANON & AUDC \\
\hline \multirow[t]{2}{*}{ HOTLINE } & Spearman correlation & $0.308^{* *}$ & 1 & & & & & & & \\
\hline & Sig. (two-tailed) & 0.000 & & & & & & & & \\
\hline \multirow[t]{2}{*}{ LTA } & Spearman correlation & 0.086 & $0.387 * *$ & 1 & & & & & & \\
\hline & Sig. (two-tailed) & 0.376 & 0.000 & & & & & & & \\
\hline \multirow[t]{2}{*}{ INV } & Spearman correlation & 0.127 & $0.313^{* *}$ & -0.011 & 1 & & & & & \\
\hline & Sig. (two-tailed) & 0.192 & 0.001 & 0.910 & & & & & & \\
\hline \multirow[t]{2}{*}{ SEG } & Spearman correlation & 0.003 & $0.314^{* *}$ & $0.335 * *$ & 0.163 & 1 & & & & \\
\hline & Sig. (two-tailed) & 0.978 & 0.001 & 0.000 & 0.094 & & & & & \\
\hline \multirow[t]{2}{*}{ XLIST } & Spearman correlation & 0.157 & $0.374 * *$ & $0.329 * *$ & 0.142 & 0.159 & 1 & & & \\
\hline & Sig. (two-tailed) & 0.107 & 0.000 & 0.001 & 0.143 & 0.103 & & & & \\
\hline \multirow[t]{2}{*}{ SUP } & Spearman correlation & $0.458 * *$ & $0.414^{* *}$ & $0.280 * *$ & 0.133 & 0.115 & 0.155 & 1 & & \\
\hline & Sig. (two-tailed) & 0.000 & 0.000 & 0.004 & 0.172 & 0.237 & 0.111 & & & \\
\hline \multirow[t]{2}{*}{ ANON } & Spearman correlation & $0.558^{* *}$ & $0.456^{* *}$ & $0.202 *$ & $0.213 *$ & 0.146 & 0.151 & $0.372 * *$ & 1 & \\
\hline & Sig. (two-tailed) & 0.000 & 0.000 & 0.037 & 0.028 & 0.133 & 0.121 & 0.000 & & \\
\hline \multirow[t]{2}{*}{ AUDC } & Spearman correlation & 0.157 & 0.165 & $0.301 * *$ & -0.012 & 0.150 & $0.287 * *$ & $0.231 *$ & 0.128 & 1 \\
\hline & Sig. (two-tailed) & 0.106 & 0.090 & 0.002 & 0.899 & 0.123 & 0.003 & 0.016 & 0.188 & \\
\hline \multirow[t]{2}{*}{ SUB } & Spearman correlation & 0.071 & 0.035 & 0.033 & 0.036 & $-0.227 *$ & -0.003 & -0.114 & 0.030 & -0.079 \\
\hline & Sig. (two-tailed) & 0.465 & 0.718 & 0.738 & 0.715 & 0.019 & 0.977 & 0.242 & 0.758 & 0.420 \\
\hline
\end{tabular}

DSCORE whistle-blowing disclosure score measured on an 18-point scale, higher scores indicating greater disclosures; HOTLINE indicator variable coded ' 1 ' if hotlines are used, ' 0 ' otherwise; LTA log of total assets in dollars; INV natural logarithm of current inventories in dollars; SEG number of geographical business segments; XLIST indicator variable coded ' 1 ' if company cross-lists in the US, ' 0 ' otherwise; SUP indicator variable coded ' 1 ' if support for whistle-blowing is explicitly mentioned in a company's whistle-blowing policy, ' 0 ' otherwise; $A N O N$ indicator variable coded ' 1 ' if company allows anonymous reporting, ' 0 ' otherwise; AUDC number of external directors on the audit committee; SUB percentage held by largest substantial shareholder

** Significant at the $1 \%$ level; * significant at the $5 \%$ level using a two-tailed test

The results do not provide support for a contention that size, level of inventory, the number of business segments and cross-listing status in the US affect the extent of disclosures made within the company's whistle-blowing policy. A possible cause for the insignificance of the coefficient on the size variable (LTA) is a lack of variation because most of the companies included in the sample are large companies. The insignificance of the coefficient on 
Table 5 Examination of factors associated with the extent of whistle-blowing disclosure

\begin{tabular}{|c|c|c|c|c|c|}
\hline & Predicted sign & Coefficient & SE & $t$ value & $p$ value \\
\hline LTA & + & -0.261 & 0.155 & -1.69 & 0.095 \\
\hline INV & + & -0.037 & 0.030 & -1.24 & 0.219 \\
\hline SEG & + & -0.084 & 0.206 & -0.41 & 0.683 \\
\hline XLIST & + & 0.359 & 0.841 & 0.43 & 0.670 \\
\hline SUP & + & $2.108 * *$ & 0.541 & 3.89 & 0.000 \\
\hline ANON & + & $3.299 * *$ & 0.526 & 6.27 & 0.000 \\
\hline AUDC & + & $0.463^{*}$ & 0.227 & 2.04 & 0.044 \\
\hline SUB & + & $0.046^{*}$ & 0.022 & 2.10 & 0.038 \\
\hline Constant & & 10.523 & 3.061 & 3.44 & 0.001 \\
\hline
\end{tabular}

$N: 107$

Log likelihood: -236.229

$\chi^{2}: 99.31, p=0.000$

Pseudo $R^{2}: 0.1234$

The table reports the results of a Tobit regression of a disclosure score (DSCORE) measuring extent of overall disclosure of whistle-blowing policies on factors predicted to be associated with use of a whistle-blowing system

DSCORE whistle-blowing disclosure score measured on an 18-point scale, higher scores indicating greater disclosures; LTA log of total assets in dollars; INV natural logarithm of the value current inventories in dollars; SEG number of geographical business segments; XLIST indicator variable coded ' 1 ' if company cross-lists in the US, ' 0 ' otherwise; SUP indicator variable coded ' 1 ' if support for whistle-blowing is explicitly mentioned in a company's whistle-blowing policy, ' 0 ' otherwise; ANON indicator variable coded ' 1 ' if company allows anonymous reporting, ' 0 ' otherwise; $A U D C$ number of external directors on the audit committee; $S U B$ percentage held by largest substantial shareholder

** Significant at the $1 \%$ level; * significant at the $5 \%$ level using a one-tailed test

cross-listing in the US variable (XLIST) could be due to the large number of zero values. A possible explanation for the insignificant result for the business segment (SEG) variable is a lack of variation in the data.

\section{Logistic Regression Analysis of the Provision} of Hotlines

An effective whistle-blowing system not only requires developing a good policy, but also the implementation of mechanisms to implement the system. In our second analysis, the dependent variable is the provision of a hotline service, as disclosed in a company's whistle-blowing policy. The results of the logistic regression are presented in Table 6. The model has significant explanatory power $\left(\chi^{2}=61.95, p=0.000\right)$ and has a pseudo $R^{211}$ of $44 \%$. The Hosmer and Lemeshow test is insignificant $(p=0.84)$ indicating that the model is of a good fit. The classification rate is $82.2 \%$, suggesting the model predicts reasonably well.

We find six variables to be significant in determining the provision of hotlines. Three of the significant variables are determinants related to the economic environment. Coefficients of the size of the firm (LTA) factors, the level of

\footnotetext{
11 The pseudo $R^{2}$ presented in the analysis is the Cox and Snell $R^{2}$. The Nagelkerke $R^{2}$ is $59.9 \%$.
}

current inventory (INV) and the number of geographical business segments (SEG) are all positive and significant at the $5 \%$ level. This finding suggests that economic determinants influence the provision of hotlines. The fourth significant variable, the cross-listing variable (XLIST), is a proxy variable for the legal environment. XLIST is significant at the $5 \%$ level $(p=0.031)$ and this suggests that the legal environment plays a significant role in the establishment of reporting procedures. Even though SOX does not mandate use of a hotline many cross-listed companies do provide this channel of reporting.

We find that determinants related to the ethical environment are positively associated with the provision of hotlines. Organisational support (SUP) and the permissibility of reporting (ANON) are positively significant at the $5 \%$ level. This finding suggests that the ethical environment affects the provision of hotline services. All variables are significant in this model except ANON and AUDC. This indicates that factors related to the corporate governance environment do not increase the probability of the provision of hotlines. Consistent with establishing a hotline requiring more time, effort and resources, the results suggest that considerations in establishing a hotline include economic and legal factors.

Overall, the results suggest that the extent of whistleblowing disclosures is determined by stronger corporate governance such as a higher number of external directors 
Table 6 Examination of factors associated with the establishment of hotlines

\begin{tabular}{|c|c|c|c|c|c|c|}
\hline & Predicted sign & Coefficient & SE & Wald & $p$ value & $\operatorname{Exp}(B)$ \\
\hline LTA & + & $0.512 *$ & 0.245 & 4.360 & 0.037 & 1.669 \\
\hline INV & + & $0.103 *$ & 0.048 & 4.627 & 0.031 & 1.109 \\
\hline SEG & + & $0.511^{*}$ & 0.257 & 3.959 & 0.047 & 1.666 \\
\hline XLIST & + & $3.381 *$ & 1.567 & 4.657 & 0.031 & 29.414 \\
\hline SUP & + & $1.272 *$ & 0.607 & 4.388 & 0.036 & 3.569 \\
\hline ANON & + & $1.340^{*}$ & 0.623 & 4.628 & 0.031 & 3.817 \\
\hline AUDC & + & -0.202 & 0.288 & 0.498 & 0.483 & 0.817 \\
\hline SUB & + & 0.041 & 0.028 & 2.148 & 0.143 & 1.042 \\
\hline Constant & & $-16.280 * *$ & 5.613 & 8.413 & 0.004 & 0.000 \\
\hline \multicolumn{7}{|l|}{$N: 107$} \\
\hline \multicolumn{7}{|c|}{-2 Log likelihood: 79.493} \\
\hline \multicolumn{7}{|c|}{$\chi^{2}: 61.954, p=0.000$} \\
\hline \multicolumn{7}{|l|}{ Pseudo $R^{2}: 0.440$} \\
\hline Prediction ratio: 82.2 & & & & & & \\
\hline
\end{tabular}

The table reports the results of a logistic regression of an indicator variable for the use of a hotline service on factors predicted to be associated with use of an effective whistle-blowing system

HOTLINE indicator variable coded ' 1 ' if hotlines are used, ' 0 ' otherwise; LTA log of total assets in dollars; INV natural logarithm of the value of current inventories in dollars; SEG number of geographical business segments; XLIST indicator variable coded ' 1 ' if company cross-lists in the US, '0' otherwise; SUP indicator variable coded ' 1 ' if support for whistle-blowing is explicitly mentioned in a company's whistle-blowing policy, ' 0 ' otherwise; $A N O N$ indicator variable coded ' 1 ' if company allows anonymous reporting, ' 0 ' otherwise; AUDC number of external directors on the audit committee; $S U B$ percentage held by largest substantial shareholder

** Significant at the $1 \%$ level; * significant at the $5 \%$ level using a one-tailed test

on the audit committee and the existence of more concentrated substantial shareholdings; and also by ethical factors such as the permissibility of anonymous reporting and management support of whistle-blowing. The implementation of a hotline service is found to be affected by economic, legal and ethical factors. The results find that firms are more likely to provide a hotline service when they are larger in size, have a higher level of current inventory, cross-listed in the US, permit anonymous reporting and when they are supportive of whistle-blowing.

\section{Sensitivity Analysis and Limitations}

\section{Other Potential Determinants}

The implementation of a whistle-blowing system might be influenced by other substitute mechanisms such as the company's external auditor. A sensitivity analysis using an indicator variable for a Big 4 auditor was conducted but we found no significant association with the use of a Big 4 auditor. We also use an alternate measure for firm size by using the number of employees instead of the natural logarithm of total assets. There is no data available for two firms, leaving a sample of 105 firms for this analysis. The results are similar to the primary results reported.

\section{Industry Effects}

We examine whether the extent of whistle-blowing disclosure and the provision of hotlines are affected by industry. The results suggest that being in the telecommunication industry decreases the extent of whistle-blowing disclosure $(p=0.009)$ but there are no other industry effects. We do not find any industry effects for the provision of hotlines. Due to the small sample we report the more parsimonious model without industry effects.

\section{Alternate Measure of Disclosure Score}

The results are robust to reasonable alternate measures of the disclosure score. For example, an alternative measure of the whistle-blowing disclosure scores can be produced by grouping the scores into higher and lower disclosures scores, and re-estimating using a logistic regression. The two groups are disaggregated using the median disclosure score. Higher disclosures scores are indicated using ' 1 ', while lower disclosures scores are coded ' 0 '. The results of the disclosure model are similar to the primary results, except that the coefficient for the number of external directors on the audit committee variable (AUDC) is no longer significant at the $5 \%$ level. Another approach was to identify 10 of the (arguably) more important disclosures 
(items $2,3,6,8,9,11,13,15,16,17$ ) and the results are similar to the primary results, except that the coefficient for substantial shareholdings (SUB) is no longer significant at the $5 \%$ level.

\section{Limitations}

The limitations to this study include the following. The results of this study may not be generalisable to smaller companies, private companies and not-for-profit entities because only larger companies were examined. The results also need to be interpreted with respect to the specific legislative context in Australia where there is legislative protection for shareholders. Finally, consistent with other studies of this type, we can only examine observable disclosures made by companies and not actual whistle-blowing practices. ${ }^{12}$ Future research on actual whistle-blowing practises is needed where access to such data allows.

\section{Conclusion}

Assuming that a whistle-blowing system requires a high level of disclosure to employees to be effective, this study examines the disclosures made within a firm's whistleblowing policy, and also in establishing a reporting hotline service; and the factors associated with these disclosures. Factors examined included the size of the firm, the level of inventory, geographical dispersion of the firm, cross-listing in the US, organisational support for whistle-blowing, permissibility of anonymous reporting, the number of external directors on the audit committee and the existence of concentrated shareholdings.

The extent of whistle-blowing disclosures was found to be positively associated with the number of external directors on the audit committee, the existence of more concentrated substantial shareholdings, the permissibility of anonymous reporting and organisational support for whistle-blowing. The findings suggest that with a stronger ethical environment and with better corporate governance, firms are more likely to disclose more in their whistleblowing policy. This in turn, would be expected to enhance the firm's whistle-blowing system.

Studies have suggested that the adoption of ethical codes may lack credibility as the presence of codes could only be a symbolic side of ethics management, and policies may not be put into actual practice (Hassink et al. 2007; Weaver et al. 1999). To this extent, we examine the establishment of hotlines. The establishment of dedicated and highly

\footnotetext{
12 We cannot tell whether some companies have whistle-blower policies not documented on their corporate website. Some companies were contacted but were not willing to provide further information.
}

visible reporting mechanism enhances credibility. Because the implementation of hotlines is costly, it is also a signal of the management's commitment to a whistle-blowing system. In this analysis, the results indicate that there is a greater likelihood of the provision of hotlines when companies are larger in size, have a higher level of current inventory, cross-listed in the US, permit anonymous reporting and when companies are supportive of whistleblowing.

Taken together, the findings of this study suggest that the ethical and corporate governance environment is important in driving the policy-making behind a whistle-blowing system. In particular, the findings indicate that stronger corporate governance lead to a greater extent of whistle-blowing disclosures. Nonetheless, this study shows that when implementing an effective whistle-blowing system, reliance on good corporate governance is insufficient. The results indicate that when it comes to implementing a hotline, firms also consider the economic cost and benefits of establishing the whistle-blowing mechanism and their legal environment.

Future research is, however, needed on the effectiveness of whistle-blowing systems where access to data permits. While there is an assumption underpinning legislation and standards that whistle-blowing is an effective method to detect fraud there is a general absence of systematic empirical research to support this contention within a corporate environment.

Acknowledgments We gratefully acknowledge the very helpful comments from Elizabeth Carson, Gary Monroe, George Tanewski, participants at the AFAANZ 2011 Darwin conference, and the research seminar of the Australian National University and Macquarie University. We also thank Libby Zhang for the provision of crosslisting data.

\section{References}

ACFE. (2010). Report to the nation on occupational fraud and abuse. Austin, TX: Association of Certified Fraud Examiners.

Adams, J. S., Tashchian, A., \& Shore, T. H. (2001). Codes of ethics as signals for ethical behavior. Journal of Business Ethics, 29, 199-211.

Appelbaum, S. H., Cottin, J., Paré, R., \& Shapiro, B. T. (2006). Employee theft: From behavioural causation and prevention to managerial detection and remedies. Journal of American Academy of Business, 9, 175-182.

Asgary, N., \& Mitschow, M. C. (2002). Toward a model for international business ethics. Journal of Business Ethics, 36, 239-246.

Ashbaugh-Skaife, H., Collins, D. W., \& Kinney, W. R, Jr. (2007). The discovery and reporting of internal control deficiencies prior to sox-mandated audits. Journal of Accounting and Economics, 44, $166-192$

Barnett, T., Cochran, D. S., \& Taylor, G. S. (1993). The internal disclosure policies of private-sector employers: An initial look at their relationship to employee whistle-blowing. Journal of Business Ethics, 12, 127-136. 
Bedard, J. C., Deis, D. R., Curtis, M. B., \& Jenkins, J. G. (2008). Risk monitoring and control in audit firms: A research synthesis. Auditing: A Journal of Practice and Theory, 27, 187-218.

Beneish, M. D., \& Chatov, R. (1993). Corporate codes of conduct: Economic determinants and legal implications for independent auditors. Journal of Accounting and Public Policy, 12, 3-35.

Bierstaker, J. L., Brody, R. G., \& Pacini, C. (2006). Accountants' perceptions regarding fraud detection and prevention methods. Managerial Auditing Journal, 21, 520-535.

Bjørkelo, B., Einarsen, S., Nielsen, M. B., \& Matthiesen, S. B. (2010). Silence is golden? Characteristics and experiences of selfreported whistle-blowers. European Journal of Work and Organizational Psychology, 20, 206-238.

Bowden, P., \& Smythe, V. (2009). Contemporary issues in international corporate governance (1st ed.). Victoria: Tilde University Press.

Bowen, R. M., Andrew, C. C., \& Rajgopal, S. (2010). Whistleblowing: Target firm characteristics and economic consequences. The Accounting Review, 85, 1239-1271.

Brown, A. J. (2009). Whistle-blowing legislation in Queensland, the agenda for reform. Final report to the Queensland Government of the Australian Research Council Linkage Project: Whistling while they work: Enhancing the theory and practice of internal witness management in public sector organisation. Griffith University.

Calderón-Cuadrado, R., Álvarez-Arce, J. L., Rodríguez-Tejedo, I., \& Salvatierra, S. (2009). "Ethics hotlines" in transnational companies: A comparative study. Journal of Business Ethics, 88, 199-210.

Chung, J., Monroe, G. S., \& Thorne, L. (2004). An examination of factors affecting external and internal whistle-blowing by auditors. Working paper, York University, Toronto.

Clarkson, P., Van Bueren, A. L., \& Walker, J. (2006). Chief executive officer remuneration disclosure quality: Corporate responses to an evolving disclosure environment. Accounting and Finance, 46, 771-796.

Coram, P., Ferguson, C., \& Moroney, R. (2008). Internal audit, alternative internal audit structures and the level of misappropriation of assets fraud. Accounting and Finance, 48, 543-559.

Davidson, R., Goodwin-Stewart, J., \& Kent, P. (2005). Internal governance structures and earnings management. Accounting and Finance, 45, 241-267.

Dyck, A., Morse, A., \& Zingales, L. (2010). Who blows the whistle on corporate fraud? The Journal of Finance, 65, 2213-2253.

Hassink, H., de Vries, M., \& Bollen, L. (2007). A content analysis of whistle-blowing policies of leading European companies. Journal of Business Ethics, 75, 25-44.

Hillison, W., Pacini, C., \& Sinason, D. (1999). The internal auditor as fraud-buster. Managerial Auditing Journal, 14, 351-363.

Holder-Webb, L., Cohen, J., Nath, L., \& Wood, D. (2008). A survey of governance disclosures among US firms. Journal of Business Ethics, 83, 543-563.

Holtfreter, K. (2005). Fraud in US organisations: An examination of control mechanisms. Journal of Financial Crime, 12, 88-95.

Jensen, M. C., \& Meckling, W. H. (1976). Theory of the firm: Managerial behavior, agency costs and ownership structure. Journal of Financial Economics, 3, 305-360.

Kaplan, S. E., Pope, K. R., \& Samuels, J. A. (2010). The effect of social confrontation on individuals' intentions to internally report fraud. Behavioral Research in Accounting, 22, 51-67.
KPMG. (2009). KPMG fraud survey 2008. Australia: KPMG.

Lang, M., \& Lundholm, R. (1993). Cross-sectional determinants of analyst ratings of corporate disclosures. Journal of Accounting Research, 31, 246-271.

McDonald, G. (2000). Business ethics: Practical proposals for organisations. Journal of Business Ethics, 25, 169-184.

Meek, G. K., Roberts, C. B., \& Gray, S. J. (1995). Factors influencing voluntary annual report disclosures by US, UK and continental European multinational corporations. Journal of International Business Studies, 26, 555-572.

Mesmer-Magnus, J., \& Viswesvaran, C. (2005). Whistle-blowing in organizations: An examination of correlates of whistle-blowing intentions, actions, and retaliation. Journal of Business Ethics, 62, 277-297.

Miceli, M. P., Near, J. P., \& Dworkin, T. M. (2008). Whistle-blowing in organizations. New York: Routledge.

Miceli, M. P., Near, J. P., \& Dworkin, T. M. (2009). A word to the wise: How managers and policy-makers can encourage employees to report wrongdoing. Journal of Business Ethics, 86, 379-396.

Moberly, R. E. (2006). Sarbanes-Oxley's structural model to encourage corporate whistle-blowers. Brigham Young Law Review, 5, 1107-1109.

Near, J. P., \& Miceli, M. P. (1985). Organizational dissidence: The case of whistle-blowing. Journal of Business Ethics, 4, 1-16.

Near, J. P., \& Miceli, M. P. (1995). Effective whistle-blowing. The Academy of Management Review, 20, 679-708.

Oldendorf, I. (2007). Corporate compliance-benefit or burden? Baltic Management Review, 2, 31-40.

Pricewaterhousecoopers. (2009). The global economic crime survey: Economic crime in a downturn.

Paul, R. J., \& Townsend, J. B. (1996). Don't kill the messenger! Whistle-blowing in America-A review with recommendations. Employee Responsibilities and Rights Journal, 9, 149-161.

Salman, F. M., \& Carson, E. (2009). The impact of the Sarbanes Oxley Act on the audit fees of Australian listed firms. International Journal of Auditing, 13, 127-140.

Sarbanes-Oxley Act. (2002). PL 107-204, 116 Stat 745.

Schwartz, M. (2001). The nature of the relationship between corporate codes of ethics and behaviour. Journal of Business Ethics, 32, 247-262.

Singh, J. B. (2006). A comparison of the contents of the codes of ethics of Canada's largest corporations in 1992 and 2003. Journal of Business Ethics, 64, 17-29.

Singh, J., Carasco, E., Svensson, G., Wood, G., \& Callaghan, M. (2005). A comparative study of the contents of corporate codes of ethics in Australia, Canada and Sweden. Journal of World Business, 40, 91-109.

Somers, M. J. (2001). Ethical codes of conduct and organizational context: A study of the relationship between codes of conduct, employee behavior and organizational values. Journal of Business Ethics, 30, 185-195.

Standards Australia. (2003). AS 8004-2003 Corporate governanceWhistle-blower protection programs for entities. SAI Global.

Weaver, G. R., Trevino, L. K., \& Cochran, P. L. (1999). Corporate ethics practices in the mid-1990's: An empirical study of the fortune 1000. Journal of Business Ethics, 18, 283-294.

Worlton, A. E. (2005). EU widens scrutiny of SOX whistle-blower hotlines. Privacy in Focus (Wiley Rein LLP, http://www.wiley rein.com/publications.cfm?sp=articles\&newsletter $=4 \& i d=2201$ ). 